\title{
The effects of ascent recharge on deep exploitable aquifers on the North European Plain (a case study of the Rogoźno salt anticline, Poland)
}

\author{
Marek RASAŁA ${ }^{1}$, * and Justyna JAŻDZEWSKA ${ }^{1}$
}

1 Adam Mickiewicz University, Faculty of Geographical and Geological Sciences, Institute of Geology, Department for Hydrogeology and Water Protection, Krygowskiego 12, 61-680 Poznań, Poland

Rasała, M., Jażdzewska, J., 2017. The effects of ascent recharge on deep exploitable aquifers on the North European Plain (a case study of the Rogoźno salt anticline, Poland). Geological Quarterly, 61 (4): 962-972, doi: 10.7306/gq.1387

\begin{abstract}
In the paper, we analyse the impact of ascending brines from the Mesozoic basement on the formation of hydrogeological conditions of deep exploitable aquifers. In the North European Plain, there are numerous salt structures with associated tectonic deformations, which form migration zones of saline waters from the Mesozoic basement to the Cenozoic cover. This creates a geogenic threat to exploitable aquifers, especially in terms of groundwater exploitation conditions. Previous studies of these phenomena had been conducted on a regional scale and focused mainly on the distribution of chlorides in receiver aquifers without detailed analysis of hydrodynamical and hydrogeochemical effects of the ascent. As part of research into the topic, it is necessary at this point to develop the methodology of assessment of geogenic risks for groundwater, for example for reasons of protection of fresh groundwater resources. As the research area, a halotectonic anticline region was chosen, where the Mesozoic basement is characterized by strong tectonic deformation, and the deepest Cenozoic aquifer has a regional spread. Some simple analyses allowed to clearly identify the zones of saline groundwater ascent along tectonic discontinuities of the Mesozoic bedrock. This phenomenon causes the appearance of waters with a mineralisation up to $2000 \mathrm{mg} / \mathrm{L}$ in the exploitable aquifer. Ascent recharge through active faults causes the presence of zones with anomalously high piezometric pressure in the cover of the fault overlay. The shape of these zones is correlated with the course of tectonic deformations. Influence of geogenic pollution is greater in the marginal zones of the anticline than above it. For the full assessment of ascent impact on hydrogeological conditions of the receiver, it is necessary not only to analyse chloride concentrations, but also other groundwater components - i.e. sulphates. Hydrogeochemical analysis may allow for identification of the shallower and deeper ascent recharge zones from the Mesozoic basement. Comprehensive identification of these factors, even in the case of poor tectonic control, can contribute to optimization of groundwater exploitation and protection conditions in the areas potentially and actually threatened by ascent.
\end{abstract}

Key words: groundwater, ascending brines, hydrodynamic anomalies, hydrogeochemical anomalies, salt structures, palaeohydrogeological conditions.

\section{INTRODUCTION}

To the exploitable Cenozoic aquifer occurring above the Permian-Mesozoic structural level in the North European Plain, the main geogenic threat is the possibility of recharge by brines from the geological basement. The groundwaters of the Mesozoic aquifer are characterized by high mineralisation and often anomalously high piezometric pressures, including artesian (Dowgiałło, 1965; Bojarski, 1996). Zones particularly predisposed to transport of ascent brines to exploitable aquifers are tectonic discontinuities, often genetically related to numerous salt structures (Evans et al., 1991; Magri et al., 2009). The results of research carried out by Grube (2000) in northern Germany point to significance of ascent as a threat to fresh ground-

* Corresponding author, e-mail: mrasala@amu.edu.pl

Received: July 24, 20017; accepted: August 30, 2017; first published online: September 27, 2017 water resources. Aquifer salinisation resulting from brines, recharge from the basement and influence of salt domes are relevant for $25 \%$ of the surface area of the northern lands. This groundwater salinisation is often the reason to shut down well fields and exclude them from exploitation (Kaczor, 2006: Krawiec, 2013).

For a long time, the surface outflow of brines close to seashores and salt structures aroused special interest due to the possibility of their easy extraction for salt-making or balneology. The history of such research for the Polish Baltic coast was presented by Dowgiałło (1965). Due to prevalence of ascent-related hazards to groundwater quality in exploitable aquifers, also this problem has been analysed for many years (e.g., Macioszczyk et al., 1972; Bojarski and Sokołowski, 1994; Bojarski, 1996; Kaczor, 2006; Mullaney et al., 2009; Jezierski et al., 2014). Detailed research has allowed documenting zones of shallow and even subsurface ascent influence in the areas of salt pillows (Kucharski and Twarogowski, 1995; Kaczor, 2006), sea coasts (Dowgiałło, 1965; Burzyński et al., 1999; Krawiec, 2013) and salt domes (Kloppmann et al., 2001; Górski and Rasała, 2008). Identification of ascent recharge zones is mainly based on advanced geophysical, modelling and isotopic meth- 


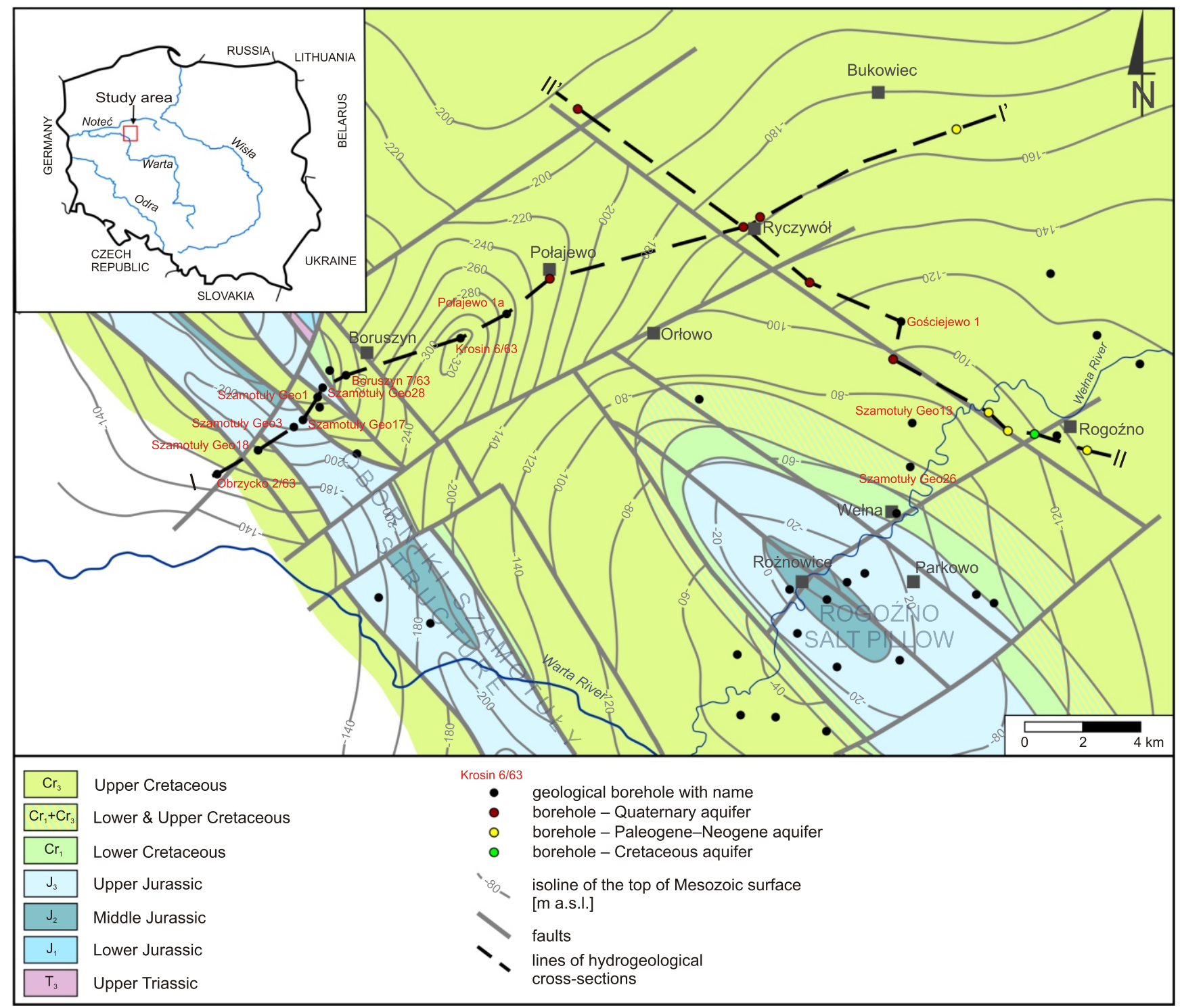

Fig. 1. Geological map of the Mesozoic basement (Atlas geostrukturalny i naftowy, 1973; modified tectonic faults and isolines, based on borehole data)

ods (e.g., Burzyński et al., 2004; Langevin and Guo, 2006; Magri et al., 2009; Zarroca et al., 2011; Gurwin and Krawiec, 2012; Krawiec, 2013). Most works on the topic concern chiefly identification of ascent recharge systems, groundwater origin, and/or distribution of elevated chloride concentrations as the most reliable indicator of ascent recharge of exploitable aquifers. However, there is no research relating to comprehensive assessment of the impact of ascent from the Mesozoic basement on shaping both hydrodynamic and hydrogeochemical conditions of the receiver aquifer. Only this type of assessment provides the ability to forecast changes in groundwater quality during exploitation. Thus, as a part of regional hydrogeological research, with protection of the quality of exploitable aquifers in mind, it is necessary to develop a proper and, as far as possible, simple and cheap methodology for at least initial identification of ascent hazards, also for aquifers already under exploitation.

The authors of the paper attempt to carry out a comprehensive assessment of hydrodynamical and hydrogeochemical effects of the ascent at selected locations based on pre-existing geological and hydrogeological documentation for the research area. Literature review shows that the least investigated problem concerns the ascent influence on deep exploitable aquifers occurring outside sea-coastal zones. Therefore, the deepest (at depths $<100 \mathrm{~m}$ below the ground) Cenozoic aquifer located in the area of young glacial moraine upland and characterized by advanced halotectonics of the geological basement was selected to perform the analysis. In the Polish Lowlands, this Miocene-Oligocene aquifer forms also the most extensive reservoir of fresh groundwater (usually of high quality), which is also the only source of drinking water for a large territory. The research area is located in the north-central part of the Wielkopolska region, in the area of two salt anticlines characterized by different geometries. In addition, there is a tectonic depression between the anticlines (Fig. 1), filled mainly by Quaternary sediments, $>200 \mathrm{~m}$ in thickness. In this area, the deepest Pleistocene aquifers are in hydraulic connection with the regional Miocene-Paleogene aquifer. The research area is crossed by the watershed between the Warta and Noteć rivers.

\section{GEOLOGICAL SETTING}

Geologically, the research area is a peripheral, NW part of the Mogilno Trough, a remainder of folding of the Permian-Me- 
sozoic sediments accumulated in the Mid-Polish Trough (Pożaryski, 1964; Dadlez and Marek, 1969; Dadlez, 1989). The trough boundary, corresponding with the boundary of the research area, is the halotectonic graben structure of Oborniki-Szamotuły (Stemulak, 1959; Krzywiec et al., 2017: fig. 17). Another halotectonic form developed within the Mogilno Trough is the Rogoźno salt pillow, which forms a brachyanticline. Zechstein deposits have not been reached by geological boreholes, but Lower Triassic deposits were drilled at a depth $\sim 1.5 \mathrm{~km}$ on the Rogoźno anticline slope. Therefore, the top of the Zechstein must occur slightly deeper there, but shallower within the culminations of the anticlines. In the anticline cores, the pre-Cenozoic basement is represented by Middle Jurassic clay-carbonate rocks and Upper Jurassic carbonates. The marginal parts of the anticlines are composed of Lower Cretaceous clastics (Fig. 1). The thickness of the Upper Cretaceous marls and limestones, which fill the synclines between the anticlines, exceeds $1 \mathrm{~km}$.

The Mesozoic basement is characterized by a high degree of tectonic deformation, which is due to salt structures development. Faults, including the detachment ones, are located in the culminating and marginal parts of the inversion structures and between them (Fig. 1). Particular lowering of the Mesozoic deposits $(-320 \mathrm{~m}$ a.s.l.) occurs between the salt structures, while the maximum elevation ( $10 \mathrm{~m}$ a.s.l.) is observed above the Rogoźno anticline. Genesis of this tectonic depression is most likely related to the migration of salt masses towards the developing salt structures (rim syncline). Thickness and development of the Cenozoic cover are determined by tectonic conditions of the Mesozoic structural level (Fig. 2).

The whole research area is covered by Paleogene-Neogene sediments, characteristic for the Polish Lowlands, such as Oligocene glauconitic sands, Miocene sands and silts with brown coal, and the Mio-Pliocene Poznań Formation clays. Relief variations of the top Neogene surface reach $210 \mathrm{~m}$ due to the presence of the so-called "Boruszyn depression" that developed in the above-mentioned lowering of the Mesozoic basement. Within its reach, the top Paleogene and Neogene surfaces are at similar elevations; on the south side, they are even lower in elevation than the Mesozoic sediments in its surroundings. The Neogene lithostratigraphic section is strongly reduced here and the depression might have formed as a result of glacial erosion, and been later remodeled by glacial tunnel valleys (Gogołek, 1999). Glacial origin of this form can be confirmed by the glaciotectonic distribution of the Neogene sediments that are observed in its SW neighbourhood (Fig. 2). The reduction of the Neogene section is visible only in the Boruszyn depression area, whereas outside the structure, sandy-coal sediments are covered by a thick complex of Mio-Pliocene clays. In contrast, above the culmination of the Rogoźno anticline there are no Paleogene deposits. The thickness of the Neogene reaches $\sim 40 \mathrm{~m}$ : that is half of the total thickness of the Cenozoic sediments.

The most complete section of Pleistocene sediments $(210 \mathrm{~m})$ is preserved as the fill of the Boruszyn depression. The glacial tills, which occur here, belong to all glaciation periods, including the Nidanian Glaciation (Szałajdewicz, 2005). In contrast, outside the area of the depression, the Quaternary section begins with Middle-Polish Glaciation sediments represented mainly by a thick complex of tills. The greatest share of the Pleistocene sandy and gravel deposits in the Quaternary section, locally only up to 40 m (Ryczywół area), is observed only in the Boruszyn depression and its marginal parts.

\section{METHODS}

In order to assess the impact of brine ascent on exploitable aquifers, the methodological assumptions were based solely on the existing data on geology and hydrogeology of the area. The authors selected this approach in a manner that it would be possible to determine whether the pre-existing documentation for an area, prepared without, e.g., advanced geophysical research, might still be sufficient to identify ascent recharge zones and their influence on the hydrodynamical and hydrogeochemical conditions of the receiver. The purpose was to check whether other comparable regional hydrogeological studies, based on classic archival data analysis, might allow for identifying potential ascent hazard. This information is crucial for groundwater resources management and for optimizing the conditions of groundwater exploitation.

The hydrogeological analysis of the research area was complemented with a geological survey, in particular in terms of lithology, structure and tectonics of the Mesozoic basement. A structural map of the base of the Quaternary deposits (Fig. 3) was developed and used to determine the reach of the deepest Pleistocene aquifers that are in hydraulic connection with the regional Miocene-Oligocene aquifer. For this purpose, the existing regional geological documentation (Atlas geostrukturalny $\mathrm{i}$ naftowy, 1973; Gogołek, 1999; Szałajdewicz, 2005) has been verified and supplemented with data from subsequent drillings.

The hydrogeological cross-sections made it possible to identify the superposition of the aquifers. To recognize the hydrodynamical conditions of the analysed exploitable aquifer, a hydrodynamic map has been developed based on recorded pressures, including verification of archival data. Initial documentation of hydrogeological conditions of the study area was based on archival data from the drilling periods. In the meantime, many of the boreholes, in which geogenic pollution had been identified, have been excluded from exploitation. Moreover, the level of spatial recognition of the Pleistocene-Miocene-Oligocene aquifer is not even, mainly due to various local land use forms and the presence of shallower exploitable aquifers. The least surveyed are the central and west parts of the research area.

\section{HYDRODYNAMIC ANALYSIS}

The exploitable aquifers in the research area are represented by Cenozoic sediments. The Quaternary aquifers are generally characterized by a limited range with a thickness up to $20 \mathrm{~m}$. The exception is the intertill aquifer related to a buried valley developed before the Warta Glaciation, whose bottom reaches a depth of $75 \mathrm{~m}$. This structure continues in the NE direction as the Main Groundwater Body (MGB) no. 139: Smogulec-Margonin Buried Valley (Fig. 3).

The recognition of pressures in Quaternary aquifers shows that a vertical hydraulic gradient occurs between those aquifers in the vast majority of the research area, showing interaquifer drainage to deeper aquifers. The exceptions are parts of the Welna and Flinta valleys, where the higher pressures are observed in the deeper, rather than in the shallower aquifers. This phenomenon is a consequence of the limited role of drainage of these rivers for the deep Pleistocene aquifers, hydraulically isolated by thicker glacial tills. The detailed hydrodynamic analysis covered the deepest Quaternary aquifers and the regional Paleogene-Neogene aquifer. 


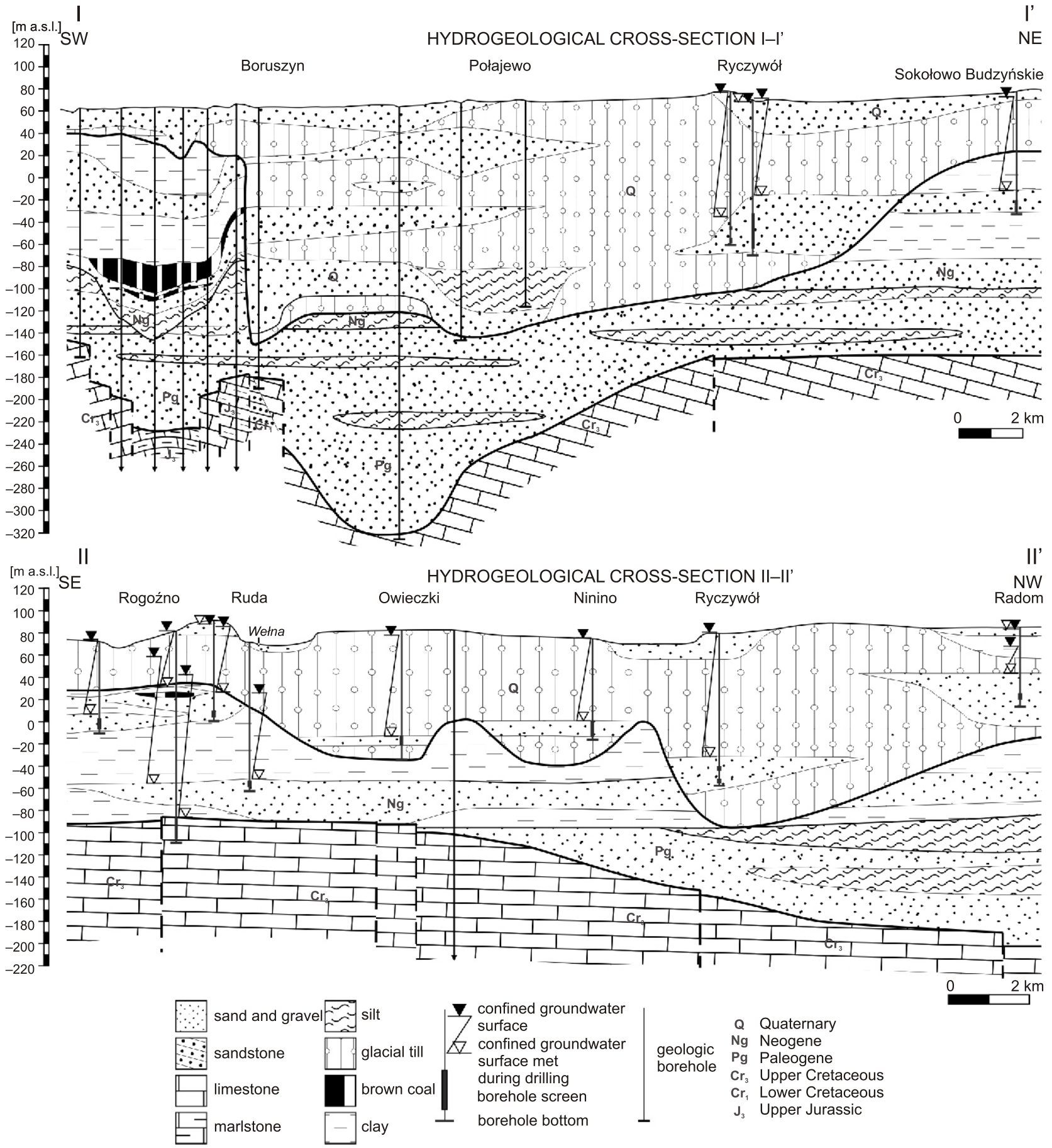

Fig. 2. Hydrogeological cross-sections of the Rogoźno anticline area

The deepest Pleistocene aquifers: lower intertill and subtill, are associated with the fill of the Boruszyn depression. Up to $20 \mathrm{~m}$ thick medium sands appear within a depth range of 120-200 m. Hydrodynamic data shows that, due to the erosion of the Neogene clays at the depression base, the deepest Pleistocene aquifers are in connection with the Oligocene fine sands that occur underneath them. They also lie at similar (and larger) depths to that of the regional Miocene-Oligocene aquifer that occurs outside the depression zone and remains in hydraulic connection with it as well. As a result, the aquifers form a common deepest exploitable aquifer.
Hydrodynamic analysis (Fig. 3) indicates that, in the northern part of the area, the deepest Quaternary aquifer associated with the Boruszyn depression can be recharged by the MGB waters. This is marked by a zone of radial distribution of the groundwater stream. The drainage of the Quaternary aquifer from the depression area takes place mainly through the Miocene-Oligocene sediments towards the Warta River. However, part of the groundwater flows in the NE direction and mixes with water of the Miocene-Oligocene aquifer from the centre of the glacial upland. The groundwater flow from this area takes place in two directions: to the north towards the Noteć River, and to 


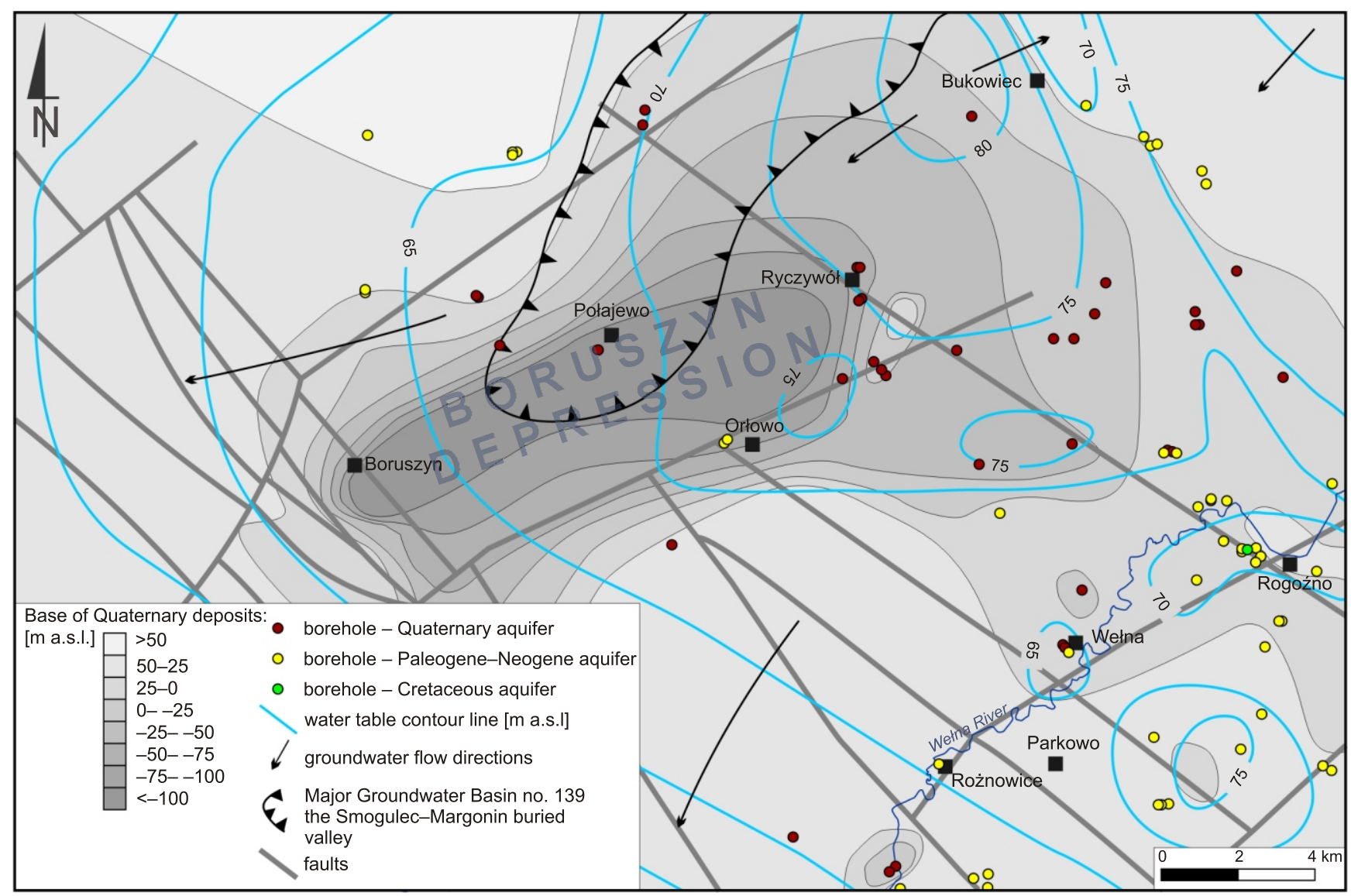

Fig. 3. Hydrodynamic map of the Pleistocene-Miocene-Oligocene aquifer, against the background of structural map of the base of Quaternary deposits

the south towards the Warta River. In the hydrodynamic picture, the drainage role of other rivers (e.g., Wełna; Figs. 2 and 3 ) is not marked.

The hydrodynamic picture of the Pleistocene-Miocene-Oligocene aquifer clearly shows zones of abnormally high piezometric pressures, as they are 5-8 $\mathrm{m}$ higher as compared to those in the surroundings (Fig. 3). They occur in the SE part of the Boruszyn depression, between Orłowo and Rogoźno, and in the Rogoźno and Parkowo area. In spite of poor geological recognition of the research area, the zones of anomalous pressures appear to be continually linear and/or linear-zonal. That indicates their association with individual faults or even fault zones:

- limiting roughly latitudinally the Rogoźno anticline from the north on the Rogoźno-Orłowo line (confined groundwater level elevations $>75 \mathrm{~m}$ a.s.l.);

- along the Wełna River, crossing laterally the NE anticline slope on the Parkowo-Rogoźno line (confined groundwater level elevations $>65 \mathrm{~m}$ a.s.I.).

The hydrodynamic anomaly east of Parkowo is elliptical; its range is determined by several boreholes (Fig. 3). Probably, it is the region of crossing of the outermost and transverse faults in relation to the anticline. The overlying lithology excludes the existence of a zone of easy groundwater inflow from the upper aquifers.

The observed anomalous pressures indicate a significant hydrodynamic pressure from the Mesozoic basement and probably an intense ascent recharge of the Cenozoic aquifer. Clear hydrodynamic impact is not marked in the anticline axis area, but only on its slopes and outside. By assuming its anom- alous linear-zonal geometry, it can be supposed that the individual faults are not hydraulically active on the entire surface. There is a possibility of occurrence of separate ascent streams flowing along the tectonic zones as an effect of, for example, local direct deposition of impermeable Paleogene sediments above these zones.

The Upper Cretaceous aquifer is not the source of hydrodynamic pressure on the deepest Cenozoic aquifer. In an almost 200 m deep borehole located in Rogoźno, the hydrostatic pressures of the Upper Cretaceous aquifer were $>2$ at. lower than the pressures in the Oligocene-Miocene succession. In contrast, limited hydrogeological data indicate that artesian pressures (artesian flow without water-table stabilization - Górecki, 1990) occur already on the NE slope of the Rogoźno anticline in Lower Cretaceous sandstones (tested at a depth 278-282 m b.g.l.). This means that the hydrostatic pressures in the Lower Cretaceous are at least 1 at. higher than in the Miocene-Oligocene aquifer, and the ascent recharge from this aquifer takes place through some of the tectonic discontinuities.

\section{HYDROGEOCHEMICAL ANALYSIS}

The chemistry of the Mesozoic aquifer that is the source of the ascent recharge was investigated only for the Lower Cretaceous aquifer and is documented by three boreholes located on the NE slope of the Rogoźno anticline. With increasing depth, a relatively small but gradual increase of groundwater mineralisation is observed. At the depth interval of $278-522 \mathrm{~m}$ b.g.l., $\mathrm{Cl}-\mathrm{Na}-\mathrm{Ca}$ type waters with mineralisation of $1800-1900 \mathrm{mg} / \mathrm{L}$ 
were found, while at a depth of $825-835 \mathrm{~m}$ b.g.l., the mineralisation was $5300 \mathrm{mg} / \mathrm{L}$ and the water type was $\mathrm{Cl}-\mathrm{Na}$ (Table 1). This is followed by a bicarbonate decrease (from 247 to $98 \mathrm{mg} / \mathrm{L}$ ) with increasing concentrations of chlorides (up to $2940 \mathrm{mg} / \mathrm{L}$ ), sodium and sulphates. In the lower sampling interval, the increase of calcium and sulphates concentrations indicates the dissolution of gypsum and/or anhydrite.

The groundwaters recharging the Lower Cretaceous sediments in pre-Cenozoic outcrops in close proximity to the recharge zone most likely mix with the ascent waters from deeper Mesozoic deposits. Then, in the shallow part of the anticline slope, the groundwaters take an artesian character and their salinity increases. Hydrochemical indicators (Table 1) show not only the deterioration of groundwater exchange conditions with depth (from the hypergene to transitional zone), but also close relationship between the chemical composition of groundwater and halite dissolution. Furthermore, among others, an unusual depth-related increase of values of desulfurization and sulphate indicators can be observed, especially in the chemical composition of the deepest zone $\left(214 \mathrm{mgSO}_{4}{ }^{2-} / \mathrm{L}\right)$, which could be related to calcium sulphate leaching. The halotectonically elevated Zechstein anhydrites, or Keuper sediments rich in sulphates, could be the source of sulphates. At the Rogoźno anticline culmination, Upper Triassic anhydrites have been documented from the depth of $770 \mathrm{~m}$ down.

Groundwater with increased concentration of chlorides (171 mg/L) was also found in the top parts of the Upper Cretaceous aquifer in Rogoźno (Table 1). The concentrations are higher than the chlorides concentration in the overlying Miocene-Oligocene aquifer ( $<157 \mathrm{mg} / \mathrm{L})$. This may also prove the ascent recharge of the Upper Cretaceous aquifer from the deeper Mesozoic basement.

The Cenozoic aquifer is locally characterized by groundwater chemical composition resulting from geogenic factors, including ascent recharge of saline waters form the Mesozoic basement. Usually, it applies to the Miocene-Oligocene aquifer. In Quaternary sediments, zones transformed by geogenic factors occur only above the Rogoźno anticline and in deeply lying aquifers of the south-eastern part of the Boruszyn depression (Table 1).

Above the anticline, geogenic influences on the Quaternary aquifer have been recognized only in the village of Wełna, where the boreholes penetrate the intertill aquifer that lies $\sim 5 \mathrm{~m}$ above the Miocene sediments. Originally, the concentration of chlorides in groundwater was $50 \mathrm{mg} / \mathrm{L}$, then, after 17 years of exploitation, it slightly increased to $64 \mathrm{mg} / \mathrm{L}$.

Significantly higher salinity with the chloride concentration of $100 \mathrm{mg} / \mathrm{L}$ was found in Wełna in the Miocene aquifer occurring directly above the outcrops of Lower Cretaceous sediments (Table 1; Wełna 1 borehole). In contrast, the highest content of chlorides $(235 \mathrm{mg} / \mathrm{L})$ in the Miocene aquifer was recorded above the Rogoźno anticline, in its culmination in Rożnowice. The ascent origin of the groundwater is confirmed by low concentrations of manganese $(<0.1 \mathrm{mg} / \mathrm{L}$; Table 1$)$, which indicate this type of recharge (Górski, 1989).

However, a zone of anomalously high chloride concentration in the Miocene aquifer above the anticline is spatially limited and correlates with the presence of a tectonic discontinuity that is transverse to the anticline and occurs along the Welna valley (Fig. 1). On the south and west slope of the anticline (the north part is not documented), the chloride concentration in the Miocene aquifer is only $15-25 \mathrm{mg} / \mathrm{L}$ (Fig. 4). It may be the effect of drainage of groundwater from the Mesozoic deposits of the $S$ and $E$ parts of the anticline through the Warta and/or other ascent-inactive tectonic discontinuities. It cannot be excluded that there are both the recharge of the Mesozoic aquifer from over- lay the overlying formations and, concurrently, the upward inflow through tectonic zones from deeper Mesozoic formations. As a result, waters with increased mineralisation occur locally above the halotectonic structure, in the Miocene. It is worth mentioning that the ascent is not reflected in hydrodynamic conditions of this aquifer above the anticline culmination, but only at its slope in the Welna region.

Within the deepest usable aquifer outside the Rogoźno anticline, groundwater with the highest dry residue, $>1500 \mathrm{mg} / \mathrm{L}$ (Fig. 4), is observed in the southern part of the Boruszyn depression (Orłowo) and west of Rogoźno (Ruda). The Oligocene-Miocene boreholes were sampled at depths of 153-162 m and 126-131 m. In both cases, they are usually of $\mathrm{Cl}-\mathrm{HCO}_{3}$ type (no analysis of macrocations) with the chloride concentrations of 540-700 mg/L. In the face of limited hydrogeological surveying of the depression area, it is impossible to identify the spatial extent of groundwater with the elevated mineralisation zone in the Orłowo region. In the west, it probably reaches beyond the village of Boruszyn, where the chloride concentrations are $\sim 110 \mathrm{mg} / \mathrm{L}$.

In contrast, the spread of saline waters in the Rogoźno town area is relatively limited (Fig. 4). In the nearby boreholes, groundwater with the dry residue of $>600 \mathrm{mg} / \mathrm{L}$ and the chloride concentrations of $>50 \mathrm{mg} / \mathrm{L}$ is found only occasionally. These values are significantly above the upper limit of hydrogeochemical background for the Wielkopolska region (Górski, 1989). This situation may be the result of its strong dilution by a groundwater regional inflow from the NE, and by percolation. Due to the existing hydrodynamic system, the partial drainage of saline water through the Upper Cretaceous sediments cannot be excluded. In contrast, the draining role of the Wełna River excludes the presence of a thick overburden.

The third zone of elevated dry matter, but at the level of $\sim 850 \mathrm{mg} / \mathrm{L}$, is observed in the Miocene-Oligocene aquifer in the Bukowiec area. Hydrodynamically, this is the zone of confluence of the Miocene-Oligocene groundwater from regional flow with the deep Quaternary aquifer waters migrating from the Boruszyn depression. Chemical composition of these waters is unusual, as the concentrations of sulphates are much higher $(146 \mathrm{mg} / \mathrm{L})$ than of chlorides $(84 \mathrm{mg} / \mathrm{L})$. These waters are the anionic type of $\mathrm{HCO}_{3}-\mathrm{SO}_{4}-\mathrm{Cl}$. Chemically similar waters occur south of this borehole, including in the Ryczywół area, within the deepest Quaternary aquifers, and south of Rogoźno on the Miocene-Oligocene aquifer. In these zones, the sulphate concentrations exceed $50 \mathrm{mg} / \mathrm{L}$ or even $100 \mathrm{mg} / \mathrm{L}$, and the chloride concentrations are up to $15 \mathrm{mg} / \mathrm{L}$.

In the light of hydrodynamic data and low concentrations of chlorides, the origin of the chemical composition of the above-mentioned groundwaters is not the result of ascent of mineralised water. However, the depth of the analysed zone excludes the impact of anthropogenic sources. Also due to the depth, the effects of organic matter or sulphide oxidation could be eliminated (lack of infiltration recharge by oxygen-rich waters). The simplest explanation of the existence of anomalous sulphate concentrations could be the dissolution of gypsum found in the Poznań Formation (Duczmal-Czernikiewicz, 2013) or in the deposits of palaeomorphological lows. However, the zones of elevated calcium concentrations do not overlap the zones of abnormally high sulphate concentrations (Fig. 4). In addition, the low concentrations of manganese in these waters (typically $<0.1 \mathrm{mg} / \mathrm{L}$ ) indicate limited recharge from the overlying formations (Górski, 1989). In contrast, lack of analysis of sodium ion concentrations (Table 1) restricts the possibility of searching for causes in the ion exchange processes.

The above-mentioned arguments lead to searching for other causes of the elevated sulphate concentrations. Due to 
Summary of selected archival physical-chemical

\begin{tabular}{|c|c|c|c|c|c|c|c|c|c|}
\hline \multirow{2}{*}{\multicolumn{2}{|c|}{ Unit }} & \multicolumn{8}{|c|}{ Borehole } \\
\hline & & \multirow{2}{*}{$\begin{array}{c}\text { Szamotuły } \\
\text { Geo26 }\end{array}$} & \multirow{2}{*}{\begin{tabular}{c|}
$\begin{array}{c}\text { Szamotuły } \\
\text { Geo13 }\end{array}$ \\
$518-522$ \\
\end{tabular}} & \multirow{2}{*}{$\begin{array}{c}\text { Gościejewo } \\
1 \\
825-835\end{array}$} & \multirow{2}{*}{\begin{tabular}{|c|} 
Rogoźno 1 \\
$169-188$
\end{tabular}} & \multirow{2}{*}{$\begin{array}{c}\text { Rogoźno } 2 \\
96-106\end{array}$} & \multirow{2}{*}{\begin{tabular}{c|} 
Rogoźno 3 \\
$91-97$
\end{tabular}} & \multirow{2}{*}{\begin{tabular}{c|} 
Rogoźno 4 \\
$96-117$
\end{tabular}} & \multirow{2}{*}{\begin{tabular}{|c|} 
Rogoźno 5 \\
$80-86$
\end{tabular}} \\
\hline Sampling interval & m b.g.l. & & & & & & & & \\
\hline Stratigraphy & & $\mathrm{Cr}_{1}$ & $\mathrm{Cr}_{1}$ & $\mathrm{Cr}_{1}$ & $\mathrm{Cr}_{3}$ & $\mathrm{Ng}$ & $\mathrm{Ng}$ & $\mathrm{Ng}$ & $\mathrm{Ng}$ \\
\hline Year of sampling & & 1959 & 1958 & 1957 & 1956 & 1962 & 1968 & 1981 & 1968 \\
\hline TDS & $\mathrm{mg} / \mathrm{L}$ & 1920 & 1760 & 5300 & $807^{*}$ & $360^{*}$ & $550^{*}$ & $356^{*}$ & $664^{*}$ \\
\hline $\mathrm{pH}$ & & & & & 7.3 & 7.2 & 7.2 & 7.4 & 7.2 \\
\hline Colour & $\mathrm{mgPt} / \mathrm{L}$ & & & & 13 & 28 & 48 & 23 & 33 \\
\hline $\mathrm{HCO}_{3}^{-}$ & $\mathrm{mg} / \mathrm{L}$ & 246.9 & 199.8 & 97.6 & & 359.9 & 457.5 & & 427.0 \\
\hline $\mathrm{SO}_{4}{ }^{2-}$ & $\mathrm{mg} / \mathrm{L}$ & 22.4 & 30.2 & 214.0 & 26.0 & 106.0 & 7.0 & 10.0 & 50.0 \\
\hline $\mathrm{Cl}^{--}$ & $\mathrm{mg} / \mathrm{L}$ & 828.9 & 874.6 & 2936.5 & 171.0 & 13.0 & 93.0 & 100.0 & 157.0 \\
\hline $\mathrm{Ca}^{2+}$ & $\mathrm{mg} / \mathrm{L}$ & 206.0 & 99.0 & 141.5 & 7.0 & & & 60.0 & \\
\hline $\mathrm{Mg}^{2+}$ & $\mathrm{mg} / \mathrm{L}$ & 9.5 & 6.6 & 35.7 & 44.0 & & & 24.2 & \\
\hline $\mathrm{Na}^{+}$ & $\mathrm{mg} / \mathrm{L}$ & $611.6^{* *}$ & $564.5^{* *}$ & $1766.6^{* *}$ & & & & & \\
\hline $\mathrm{Fe}$ & $\mathrm{mg} / \mathrm{L}$ & & & & 3.6 & 1.2 & 1.2 & 0.2 & 2.0 \\
\hline $\mathrm{Mn}$ & $\mathrm{mg} / \mathrm{L}$ & & & & 0.02 & 0.15 & 0.07 & & 0.18 \\
\hline Total hardness & $\mathrm{mval} / \mathrm{L}$ & & & & & 4.3 & 6.3 & 5.1 & 5.9 \\
\hline $\mathrm{N}-\mathrm{NH}_{4}{ }^{+}$ & $\mathrm{mg} / \mathrm{L}$ & & & & 0.6 & 0.5 & 0.4 & & 0.7 \\
\hline $\mathrm{N}-\mathrm{NO}_{2}^{-}$ & $\mathrm{mg} / \mathrm{L}$ & & & & 0.2 & 0.5 & 0.0 & & 0.0 \\
\hline $\mathrm{N}-\mathrm{NO}_{3}^{-}$ & $\mathrm{mg} / \mathrm{L}$ & & & & 0.0 & 0.0 & 0.0 & 0.1 & 0.0 \\
\hline \multicolumn{2}{|l|}{$\mathrm{rNa} / \mathrm{rCl}$} & 1.14 & 0.99 & 0.93 & & & & & \\
\hline \multicolumn{2}{|l|}{$\mathrm{rCl} / \mathrm{rHCO}_{3}$} & 5.78 & 7.53 & 51.77 & & 0.06 & 0.35 & & 0.63 \\
\hline \multicolumn{2}{|l|}{$\left(\mathrm{rSO}_{4}+\mathrm{rHCO}_{3}\right) / \mathrm{rCl}$} & 0.19 & 0.16 & 0.07 & 0.11 & 22.11 & 2.91 & 0.07 & 1.82 \\
\hline \multicolumn{2}{|c|}{$\begin{array}{l}\mathrm{rSO}_{4} /\left(\mathrm{rSO}_{4}+\mathrm{rCl}\right) \\
\text { (desulfurization indicator) }\end{array}$} & 0.02 & 0.02 & 0.05 & 0.10 & 0.86 & 0.05 & 0.07 & 0.19 \\
\hline \multicolumn{2}{|l|}{$\begin{array}{l}\left(\mathrm{rSO}_{4}{ }^{*} 100\right) / \mathrm{rCl} \\
\text { (sulphate indicator) }\end{array}$} & 2.00 & 2.55 & 5.38 & 11.23 & 602.20 & 5.56 & 7.39 & 23.52 \\
\hline \multicolumn{2}{|c|}{$\begin{array}{l}\text { Chemical type according to } \\
\text { Altowski-Szwiec classifica- } \\
\text { tion }\end{array}$} & $\mathrm{Cl}-\mathrm{Na}-\mathrm{Ca}$ & $\mathrm{Cl}-\mathrm{Na}-(\mathrm{Ca})$ & $\mathrm{Cl}-\mathrm{Na}$ & $?$ & $\mathrm{HCO}_{3}-\mathrm{SO}_{4}-?$ & $\mathrm{HCO}_{3}-\mathrm{Cl}-?$ & $?$ & $\mathrm{HCO}_{3}-\mathrm{Cl}-?$ \\
\hline
\end{tabular}

* - dry residue; ${ }^{* *}-\mathrm{Na}+\mathrm{K} ; ?$ - no possibility of specifying because of lack of macrocation indicators

the location of these waters in the marginal parts of the Boruszyn depression and in its vicinity, it is possible that the source of sulphates is the organic matter (or possibly sulphides) oxidation, however occurring during older interglacial periods. In the pre-Quaternary period, a reservoir existed in the area currently occupied by the Boruszyn depression. Its slopes were composed of sediments rich in organic matter (Figs. 2 and 3), further disturbed and glacially elevated from the south-west. The waters of this reservoir were then recharged also by surface waters enriched in products of oxidation of the Miocene sediments. As a result of erosion, the reservoir, in turn, recharged deeper aquifers with sulphate waters which have survived to this day in a residual form. Due to the presence of intense ascent recharge, it has probably been preserved in more hydraulically isolated zones. Similar hydrodynamic isolation, associated with, e.g. ascent from the basement for the zones of coloured waters that occur in the Miocene aquifer of the Wielkopolska region was observed by Górski (1989). In the Rogoźno and Bukowiec areas, the colour of Miocene waters is quite commonly $>50 \mathrm{mgPt} / \mathrm{L}$, with a maximum of $100 \mathrm{mgPt} / \mathrm{L}$.

Another specific hydrogeochemical situation was documented by two boreholes in Orłowo. These boreholes penetrate, at a similar depth interval, the Oligocene aquifer in the southern part of the Boruszyn depression. The southern borehole explored water with the concentrations of $704 \mathrm{mgCl}^{-} / \mathrm{L}$ and $419 \mathrm{mgSO}_{4}^{2-} / \mathrm{L}$, while in the northern borehole the parameters were $538 \mathrm{mgCl}^{-} / \mathrm{L}$ and $16 \mathrm{mgSO}_{4}^{2-} / \mathrm{L}$. After two years of exploi- tation of the northern borehole, the chloride concentrations in the groundwater increased by $144 \mathrm{mg} / \mathrm{L}$, and the sulphate concentrations by $5 \mathrm{mg} / \mathrm{L}$, which was probably due to intensification of ascent under depressurization conditions. Slightly lower original concentrations of chlorides in the water from the northern borehole can be associated with its dilution by regional inflows. However, attention must be paid to the different sulphate concentrations in boreholes located at a distance of only $25 \mathrm{~m}$. It seems that the only probable explanation is the existence of two individual systems of ascent recharge of the Oligocene aquifer in the Orłowo region: a shallow one, which provides chloride waters, and a deeper one which provides chloride-sulphate water. It is also confirmed by the difference in piezometric pressures documented in these boreholes (of $\sim 0.4 \mathrm{~atm}$ ). This hypothesis is geologically justified, because Orłowo is located on the northern edge of the Rogoźno anticline, where borehole data confirm the presence of a tectonic discontinuity. In fact, it may be even a fault system. The main and associated faults can ascendingly provide groundwater from various depths, hence with various chemical compositions. The sulphate concentration indicates an upward inflow of sulphate water from the Upper Triassic (according to data from boreholes drilled here to a depth of $\sim 1300 \mathrm{~m}$ b.g.l.).

The area located to the east of Parkowo, where anomalously high piezometric pressures occur, requires additional commentary (Fig. 3). In this region, the concentrations of 
analyses of groundwater

\begin{tabular}{|c|c|c|c|c|c|c|c|c|c|c|c|}
\hline \multicolumn{12}{|c|}{ Borehole } \\
\hline Ruda & Orłowo 1 & \multicolumn{2}{|c|}{ Orłowo 2} & \multirow{2}{*}{\begin{tabular}{|c|} 
Połajewo \\
$155-177$ \\
\end{tabular}} & \multirow{2}{*}{$\begin{array}{c}\text { Połajewo } \\
2\end{array}$} & \multirow{2}{*}{\begin{tabular}{|c|}
$\begin{array}{c}\text { Ryczywół } \\
1\end{array}$ \\
$127-137$ \\
\end{tabular}} & \multirow{2}{*}{\begin{tabular}{c|}
$\begin{array}{c}\text { Ryczywół } \\
2\end{array}$ \\
$102-134$
\end{tabular}} & \multirow{2}{*}{$\begin{array}{c}\text { Bukowiec } \\
109-119\end{array}$} & \multirow{2}{*}{$\begin{array}{c}\text { Rożnowice } \\
46-50\end{array}$} & \multirow{2}{*}{$\begin{array}{c}\text { Wełna } 1 \\
60-66\end{array}$} & \multirow{2}{*}{$\begin{array}{c}\text { Wełna } 2 \\
46-52\end{array}$} \\
\hline $126-131$ & 154-161 & $154-162$ & $154-162$ & & & & & & & & \\
\hline $\mathrm{Ng}$ & $\mathrm{Pg}$ & $\mathrm{Pg}$ & $\mathrm{Pg}$ & $\mathrm{Q}$ & $\mathrm{Q}$ & $\mathrm{Q}$ & $Q$ & $\mathrm{Ng}$ & $\mathrm{Ng}$ & $\mathrm{Ng}$ & $Q$ \\
\hline 1969 & 1974 & 1963 & 1964 & 1999 & 1971 & 1959 & 1999 & 1967 & 1972 & 1969 & 1982 \\
\hline $1547^{*}$ & $1612^{*}$ & 1399* & $1640^{*}$ & $400^{*}$ & $370^{*}$ & $276^{*}$ & $492^{*}$ & $856^{*}$ & $607^{*}$ & $545^{*}$ & $521^{*}$ \\
\hline 7.3 & 7.5 & 7.6 & 7.4 & 7.4 & 7.1 & 7.4 & 7.5 & 7.4 & 7.8 & 7.4 & 7.4 \\
\hline 98 & 35 & 25 & & & & 56 & & 28 & 28 & 28 & 58 \\
\hline 433.1 & 457.5 & 457.5 & 463.6 & 445.4 & 439.2 & 189.1 & 530.9 & 219.6 & 475.8 & 427.0 & 494.10 \\
\hline 10.0 & 419.0 & 16.0 & 20.8 & 2.0 & 11.0 & 66.9 & 29.0 & 146.0 & 8.0 & 7.0 & 13.2 \\
\hline 654.0 & 704.0 & 538.0 & 682.0 & 8.0 & 6.0 & 15.0 & 12.0 & 84.0 & 235.0 & 101.0 & 50.0 \\
\hline 100.0 & & & 48.6 & 43.7 & 67.2 & & 93.6 & & & & 50.0 \\
\hline \multirow[t]{2}{*}{51.0} & & & 21.6 & 39.0 & 26.4 & & 45.4 & & & & 17.0 \\
\hline & & & & 42.9 & & & 35.1 & & & & \\
\hline 2.6 & 0.6 & 0.5 & 1.8 & 4.8 & 3.6 & 1.0 & 2.18 & 1.9 & 1.2 & 0.8 & 1.8 \\
\hline 0.13 & 0.05 & 0.00 & & 0.21 & & 0.2 & 0.07 & 0.1 & 0.05 & 0.08 & 0.05 \\
\hline 8.4 & 6.9 & 4.4 & 4.4 & & 5.5 & 4.06 & & & 3.7 & 3.40 & 3.9 \\
\hline 0.6 & 0.8 & 0.5 & 0.9 & 0.11 & 0.5 & & $<0.4$ & 0.2 & 1 & 0.5 & 0.5 \\
\hline 0.1 & 0.1 & 0.0 & 0.7 & 0.4 & 0.0 & & 0.9 & & 0.1 & 0.0 & 0.1 \\
\hline \multirow[t]{2}{*}{0.0} & 0.0 & 0.0 & 0.0 & 0.0 & 0.0 & & 0.0 & 0.0 & 0.0 & 0.0 & 0.0 \\
\hline & & & & & & & 4.51 & & & & \\
\hline 2.60 & 2.65 & 2.02 & 2.53 & 0.03 & 0.02 & 0.14 & 0.04 & 0.66 & 0.85 & 0.41 & 0.17 \\
\hline 0.40 & 0.82 & 0.52 & 0.42 & 32.54 & 43.89 & 10.62 & 27.50 & 2.80 & 1.20 & 2.51 & 5.94 \\
\hline 0.01 & 0.31 & 0.02 & 0.02 & 0.16 & 0.58 & 0.77 & 0.64 & 0.56 & 0.02 & 0.05 & 0.16 \\
\hline 1.13 & 43.96 & 2.20 & 2.25 & 18.46 & 135.40 & 329.39 & 178.48 & 128.37 & 2.51 & 5.12 & 19.50 \\
\hline $\mathrm{Cl}-\mathrm{HCO}_{3}-?$ & $\begin{array}{l}\mathrm{Cl}^{-\mathrm{SO}_{4}-} \\
\mathrm{HCO}_{3}-?\end{array}$ & $\mathrm{Cl}-\mathrm{HCO}_{3}-?$ & $\mathrm{Cl}-\mathrm{HCO}_{3}-?$ & $\begin{array}{c}\mathrm{HCO}_{3}-\mathrm{Ca} \\
-\mathrm{Mg}-\mathrm{Na}\end{array}$ & $\mathrm{HCO}_{3}-?$ & $\begin{array}{l}\mathrm{HCO}_{3^{-}} \\
\mathrm{SO}_{4^{-}} ?\end{array}$ & $\begin{array}{l}\mathrm{HCO}_{3}-\mathrm{Ca} \\
-\mathrm{Mg}-(\mathrm{Na})\end{array}$ & $\begin{array}{c}\mathrm{HCO}_{3}-\mathrm{SO}_{4} \\
-\mathrm{Cl}-?\end{array}$ & $\mathrm{HCO}_{3}-\mathrm{Cl}-?$ & $\mathrm{HCO}_{3}-\mathrm{Cl}-?$ & $\mathrm{HCO}_{3}-?$ \\
\hline
\end{tabular}

chlorides ( $<30 \mathrm{mg} / \mathrm{L}$ ) and sulphates (generally $<30 \mathrm{mg} / \mathrm{L}$ ) are not significantly elevated. It should be noted that all the boreholes exploit the Miocene aquifer, while the base of the Paleogene occurs $\sim 60-80 \mathrm{~m}$ lower. With a preferred interna hydraulic connection of the Paleogene and the Neogene, anomalous ascent pressure is noted in the Miocene aquifer. Still, saline waters may migrate through the lower part of the aquifer, whose groundwater chemistry differs from that in its upper parts.

\section{RESULTS OF THE ANALYSIS}

The analyses performed have allowed recognizing the complexity and multidimensional nature of the effect of ascent recharge on hydrogeological conditions of the Cenozoic aquifer that occurs above the Mesozoic basement. These processes are mainly influenced by the structural and tectonic style of the Mesozoic basement and its variability (salt anticline, tectonics, lithology, structural surface morphology, including palaeodevelopment), which must be reflected in the groundwater chemistry and dynamics. In hydrogeological literature, the interlinked influence of these variables in principle has not been the subject of detailed analysis.

The case study of the Rogoźno salt anticline shows that comprehensive geological and hydrogeological analysis not only allows documenting but, above all, predicting the geogenic hazards to the quality of groundwater in the overlying aquifers. For this purpose, it is useful to develop a hydrodynamical model that covers also hydrogeochemical impact. In case of the Rogoźno anticline, this model is shown in Figure 5.

Particularly complex hydrogeological relations between the Mesozoic and Cenozoic sediments were noted above the Rogoźno anticline. The ascent inflow of saline waters to the overlying aquifer was documented near one transverse fault only. However, the lateral spread of ascending groundwater is limited here, as there are most likely also local conditions for recharge of the Mesozoic aquifers through some faults and outcrops due to the occurrence of the regional base level of groundwater drainage. Probably in certain zones of the Mesozoic cover above the salt pillow, waters migrating from the overlay and from the ascent inflow (also enriched in sulphates) mix. Therefore, the Mesozoic aquifer in the shallow zones of the anticline locally has an artesian character. Hydrodynamic pressure of ascent waters does not significantly affect the distribution of hydrostatic pressures in the receiver aquifer occurring above the anticline culmination.

Significant hydrodynamic influence of ascent waters is shown in the presence of anomalously high piezometric pressures that disturb the regional groundwater flow. These pressures occur only within the overlay in the anticline surroundings. They have a local (including linear-shape) character, closely re- 


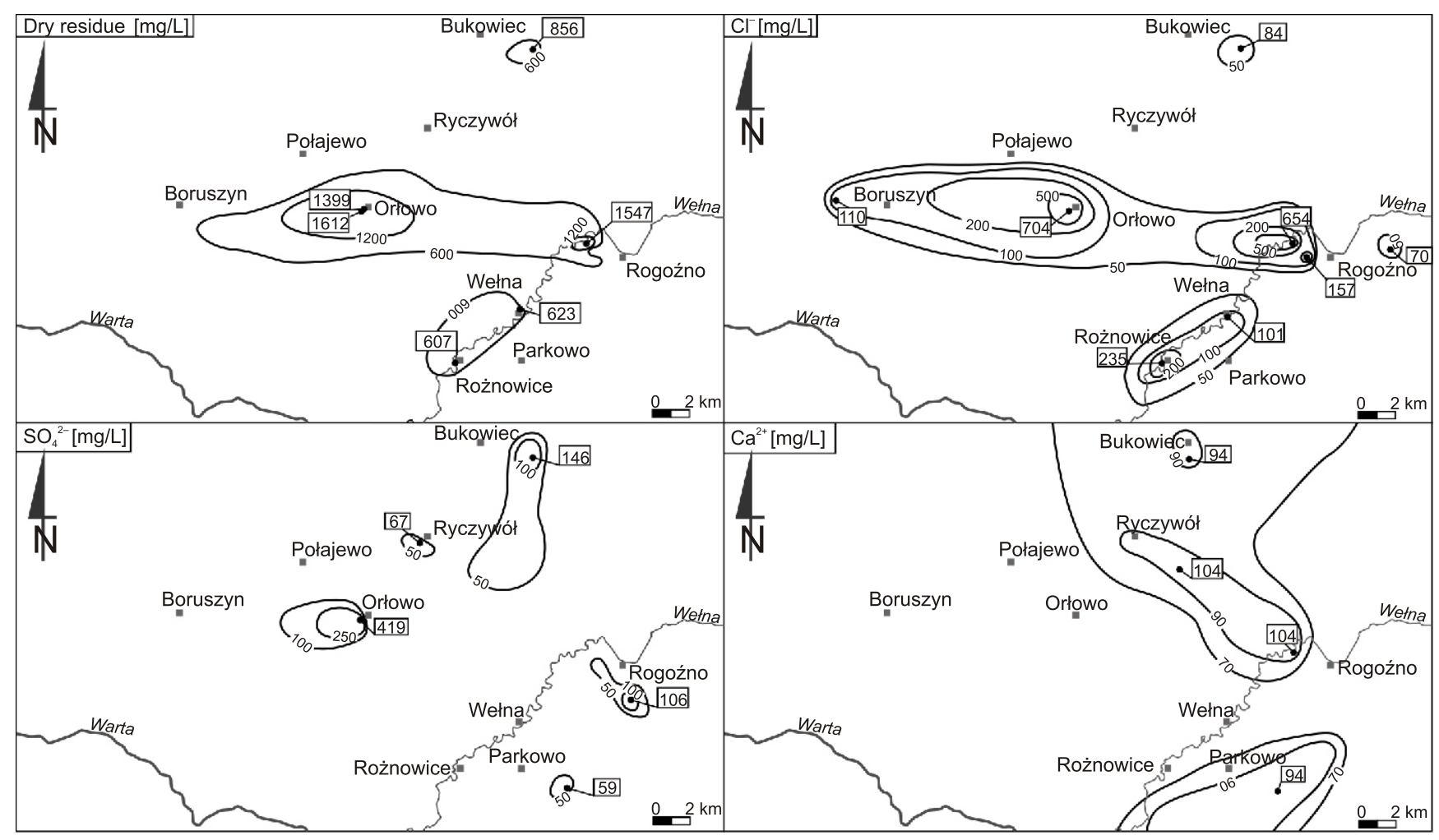

Fig. 4. Distribution maps of selected chemical parameters of the Pleistocene-Miocene-Oligocene aquifer in the Rogoźno anticline area

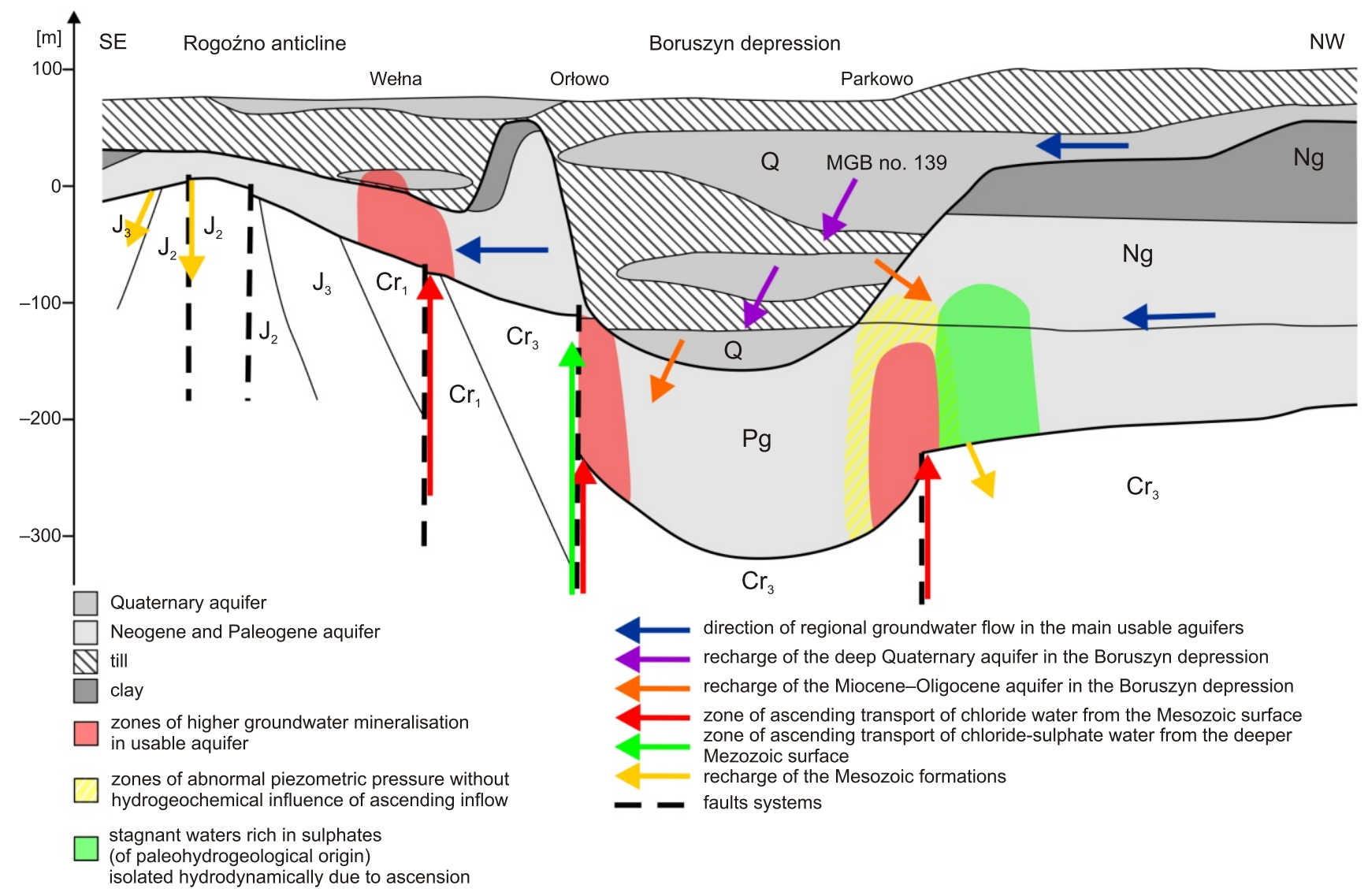

Fig. 5. Conceptual diagram of the groundwater flow system in the Rogoźno anticline area, and the influence of ascending inflow on groundwater chemistry 
lated to tectonic discontinuities - both those on the boundary of the inverse structure as well as transversing it. Ascent inflow is marked by a local, linear-shaped increase of groundwater mineralisation up to $2 \mathrm{~g} / \mathrm{L}$ in the deepest exploitable aquifer. Particular fault zones may conduct groundwater from different Mesozoic aquifers, which manifests itself in variable concentrations of chlorides and sulphates in the receiver groundwater even in boreholes located close to each other. Some of the discontinuities, and even individual zones of single faults, appear to be ascendingly inactive, which is controlled by the lithology of fault's overlay and the hydraulic parameters of the tectonic zone.

However, the hydrochemical impact of ascent waters is not necessarily reflected in the entire profile of the overlying aquifer. It may be limited to its lower parts, despite the hydrodynamic anomalies noted also in its upper parts. In addition to the thickness of the aquifer, the codetermining factor here may be the hydrodynamic relations that allow for parallel recharge from the overlying aquifer, thus undermining the pressure effect of the ascent on the receiver.

The occurrence of zones of elevated sulphate and low chloride concentrations can be assocated with palaeohydrogeological conditions. These zones often coincide with ascent recharge zones. Presumably, in isolating hydrodynamic conditions, the fossil waters, enriched with products of organic matter and/or sulphide oxidation from the top Neogene deposits, have been preserved. The receiver of sulphate water could be the reservoir that existed within the Boruszyn depression in the interglacial periods, and which simultaneously recharged deeper aquifers.

\section{CONCLUSIONS}

To counterbalance the multiplicity of salt structures on the North European Plain (only in Poland there are 100 such structures - Dadlez and Marek, 1969), even simple, though detailed analyses of hydrodynamic and hydrogeochemical anomalies may be sufficient for the assessment of ascent recharge impact and prognosis for exploitable aquifers, without resorting to expensive geological and/or modelling methods. However, the ascending inflow impact can manifest itself in a variety of ways. While the coexistence of hydrodynamic and hydrogeochemical anomalies in the receiver occurring above the ascendingly active discontinuities is not the rule, nevertheless they are a clear indicator of the inflow intensity and/or significant pressure difference between the aquifers; the spatial spread of the anomaly (linear, oval) is correlated with the course of the ascendingly active faults. Above the salt anticline culmination, only hydrogeochemical effects of the ascent are observed, without any significant hydrodynamic impact recorded. On the other hand, with a substantial aquifer thickness, ascent may hydrodynamically affect the entire profile of the aquifer, whereas changes of groundwater chemistry may occur only in its lower parts.

As part of hydrogeological research into groundwater reservoirs occurring above Mesozoic saline aquifers, it is necessary to carry out ascent risk assessment with water quality in mind. Such analyses should include both the natural and projected state under groundwater extraction conditions (initiation or intensification of ascent). With an adequate hydrogeological survey of a given area, it may be methodically sufficient for the assessment of geogenic hazards to search for potential hydrogeochemical and hydrodynamic effects of the ascent in conjunction with analysis of the structural and tectonic style of geological basement. Such methodology allows not only identifying hydraulically active zones in the case of spatially developed tectonic discontinuities, but also distinguishing shallower and deeper zones of the ascent inflow. A helpful indicator can be, for example, the sulphate concentrations.

Ascent recharge of a thick exploitable aquifer can manifest itself also only in the presence of a hydrodynamic anomaly; changes in groundwater chemistry may occur later, during exploitation - thus resulting in groundwater quality degradation. Therefore, when selecting locations for groundwater intakes during the stage of hydrogeological analysis, it is necessary to clarify the origin and effects of such anomalies. This could help optimize the working conditions of the intakes and ensure groundwater protection. In order to limit the spread of identified geogenic pollutions, one might even consider the creation of special zones excluded from exploitation or extraction of contaminated groundwater, thereby creating a hydrodynamic barrier to protect operations in other boreholes.

It is thus well justified to proceed with analogous analyses of ascension effects also for other vulnerable groundwater aquifers. This will allow verifying correctness of the approach adopted in the present paper, and, in consequence, to develop a tested research methodology for these phenomena.

Acknowledgements. The studies were supported by the statutory funds of the Institute of Geology, Adam Mickiewicz University in Poznań. We wish to thank Dr. E. Liszkowska and Prof. J. Górski for useful comments and advice, and to express our gratitude to Prof. J. Motyka and Dr. K. Ghodeif for review of the manuscript.

\section{REFERENCES}

Atlas geostrukturalny i naftowy, 1973. Część III. Ropo- i gazonośność synklinorium mogileńsko-łódzkiego na tle budowy geologicznej (in Polish). Skala 1:200 000. Instytut Geologiczny - Zjednoczone Górnictwo Naftowe.

Bojarski, L., ed., 1996. Hydrochemical and Hydrodynamic Atlas of the Paleozoic and Mesozoic and Ascensive Salinity of Ground Water in the Polish Lowlands 1:1,000,000 (in Polish with English summary). Cartographic Publishing House of the Polish Agency for Ecology, Warszawa.

Bojarski, L., Sokołowski, A., 1994. Zagrożenie ascenzyjnym zasoleniem wód zwykłych w utworach kredy dolnej niecki łódzkiej (in Polish). Przegląd Geologiczny, 42: 459-464.
Burzyński, K., Kozerski, B., Sadurski, A., 1999. Salt water intrusion and ascension processes on the Polish Baltic coast (in Polish with English summary). Biuletyn Państwowego Instytutu Geologicznego, 388: 35-48.

Burzyński, K., Krawiec, A., Sadurski, A., 2004. The origin and mobilization of deep brines to the aquifer system by considering the circulation systems existing on the Polish western coast of the Baltic Sea. Proceedings of the 18th Salt Water Intrusion Meeting, Cartagena: 521-531.

Dadlez, R., 1989. Epicontinental Permian and Mesozoic basins in Poland (in Polish with English summary). Kwartalnik Geologiczny, 33 (2): 175-198. 
Dadlez, R., Marek, S., 1969. Structural style of the Zechstein-Mesozoic complex in some areas of the Polish Lowland (in Polish with English summary). Kwartalnik Geologiczny, 13 (3): 543-565.

Dowgiałło, J., 1965. Solanki Pomorza Zachodniego (in Polish). Szczecińskie Towarzystwo Naukowe. Wydział Nauk Matematycznych i Technicznych, Szczecin, 4.

Duczmal-Czernikiewicz, A., 2013. Evidence of soils and palaeosols in the Poznań Formation (Neogene, Polish Lowland). Geological Quarterly, 57 (2): 189-204.

Evans, D.G., Nunn, J.A., Hanor, J.S., 1991. Mechanisms driving groundwater flow near salt domes. Geophysical Research Letters, 18: 927-930.

Gogołek, W., 1999. Objaśnienia do Szczegółowej Mapy Geologicznej Polski w skali 1:50 000, ark. Obrzycko (in Polish). Ministerstwo Środowiska, Warszawa.

Górecki, W., ed., 1990. Atlas of the Geothermal Waters of Polish Lowland. Early Jurassic and Early Cretaceous Reservoirs. University of Science and Technology Institute of Fossil Fuels, Kraków.

Górski, J., 1989. The main hydrochemical problems of Cainozoic aquifers located in Central Wielkopolska (Great Poland) (in Polish with English summary). Zeszyty Naukowe Akademii Górniczo-Hutniczej, 45.

Górski, J., Rasała, M., 2008. Hydrogeology of the chosen salt domes of the Kujawy region - cognitive and utilitarian aspects (in Polish with English summary). Geologos, 13, Monographiae, 5.

Grube, A., 2000. Widespread geogenic salt water occurrence in North Germany - demonstrated on the basis of a generalized map. Proceedings of the 16th Salt Water Intrusion Meeting, Międzyzdroje-Wolin Island: 55-62.

Gurwin, J., Krawiec, A., 2012. Identification of groundwater flow system of the Wolin Island (in Polish with English summary). Biuletyn Państwowego instytutu Geologicznego, 451: 53-62.

Jezierski, P., Wiśniowski, Z., Hoc, R., 2014. Zagrożenia jakości wód występowaniem jonu chlorkowego w wodach podziemnych na obszarze północno-zachodniej Polski (in Polish). Polskie Zrzeszenie Inżynierów i Techników Sanitarnych, 20: 127-138.

Kaczor, D., 2006. The salinity of groundwater in Mesozoic and Cenozoic aquifers of NW Poland - origin and evolution. Studia Geologica Polonica, 126: 5-76.

Kloppmann, W., Negrel, P., Casanova, J., Klinge, H., Schelkes, K., Guerrot, C., 2001. Halite dissolution derived brines in the vicinity of a Permian salt dome (N German Basin). Evidence from boron, strontium, oxygen, and hydrogen isotopes. Geochimica et Cosmochimica Acta; 65: 4087-4101.
Krawiec, A., 2013. The origin of chloride anomalies in the groundwaters of the Polish Baltic coast (in Polish with English summary). Wyd. Nauk. UMK. Toruń.

Krzywiec, P., Peryt, T.M., Kiersnowski, H., Pomianowski, P., Czapowski, G., Kwolek, K., 2017. Permo-Triassic evaporites of the Polish Basin and their bearing on the tectonic evolution and hydrocarbon system, an overview. In: Permo-Triassic Salt Provinces of Europe, North Africa and the Atlantic Margins. Tectonics and Hydrocarbon Potential (eds. J.I. Soto, J.F. Flinch and G. Tari): 243-262. Elsevier Publishing.

Kucharski, R., Twarogowski, J., $1995 . \quad$ Dynamika rozprzestrzeniania się zasolenia | zanieczyszczeń wód podziemnych na obszarze Ciechocinka (in Polish). Przegląd Geologiczny, 43: 483-486

Langevin, C.D., Guo, W., 2006. MODFLOW/MT3DMS-based simulation of variable-density ground water flow and transport Ground Water, 44: 339-351.

Macioszczyk, A., Pich, J., Płochniewski, Z., 1972. Chemical nature of ground waters in Tertiary formations within the area of Poland (except for the Carpathians) (in Polish with English summary). Kwartalnik Geologiczny, 16 (2): 428-445.

Magri, F., Bayer, U., Pekdeger, A., Otto, R., Thomsen, C. Maiwald, U., 2009. Salty groundwater flow in the shallow and deep aquifer systems of the Schleswig-Holstein area (North German Basin). Tectonophysics, 470: 183-194.

Mullaney, J.R., Lorenz, D.L., Arntson, A.D., 2009. Chloride in Groundwater and Surface Water in Areas Underlain by the Glacial Aquifer System, Northern United States. U.S. Geological Survey Scientific Investigations Report 2009-5086.

Pożaryski, W., 1964. Outline of Paleozoic and Mesozoic tectonics of the Polish Lowland (in Polish with English summary). Kwartalnik Geologiczny, 8 (1): 1-41.

Stemulak, J., 1959. The Szamotuły-Oborniki structure (western Poland) in view of recent drilling and geological investigation (in Polish with English summary). Kwartalnik Geologiczny, 3 (2): 296-309.

Szałajdewicz, J., 2005. Objaśnienia do Szczegółowej Mapy Geologicznej Polski w skali 1: 50 000, ark. Parkowo (in Polish). Ministerstwo Środowiska, Warszawa, $35 \mathrm{pp}$.

Zarroca, M., Bach, J., Linares, R., Pellicer, X.M., 2011. Electrical methods (VES and ERT) for identifying, mapping and monitoring different saline domains in coastal plain region (Alt Empordà, Northern Spain). Journal of Hydrology, 409: 407-422. 